\title{
平等ギャップの火花放電時の電圧・電流測定
}

\author{
正 員 松本 隆宇 (静岡大学) \\ 学生員 榊原 典尚 (静岡大学) \\ 正 員 黒川 正明 (静岡大学)
}

\section{Voltage and Current Measurement of Spark Discharge for Uniform Gap}

Takaie Matsumoto, Member, Norihisa Sakakibara ,Student Member

Masaaki Kurokawa, Member ( Shizuoka University)

\section{キーワード：火花放電，平等電界ギャップ，測定誤差，電界計算}

\section{1. はじめに}

放電現象の研究にはしばしば分割電極が用いられ，放電 電流や空間電荷電界の測定等が行われている。今回，平等 ギャップの火花放電過程の研究を行うに当たって，それら を参考にして，高速の電圧・電流測定を行うために，接地 平板電極を分割して電圧・電流の検出部を設けた広带域測 定システムを構築した。

本研究では平等電界における放電現象を対象としており, コロナが発生しないので放電によって発生する空問電荷は 火花放電路にのみ存在すると考えてよい。従って, 空間電荷 による電界変歪が小さく, 電界センサで電極電圧を測定す ることが可能であるが，火花放電路内の空間電荷によって 生じる電界の影響が測定誤差となる。また, 高電圧電極 電流検出部間の容量が不平等電界配置の場合より大きく, 電流測定の誤差要因となる。このような原因による誤差は, 測定の較正を行っても除去することができず，これまで詳 細には検討されていない。そこで，本研究ではそれらの要 因によって生じるよる誤差を電界計算を応用して定量的に 検討したので報告する。

\section{2. 測定系の概要}

実験には球（直径 $15 \mathrm{~cm}$ ）一平板の電極を用い, ギャッ プ長 $1 \sim 3 \mathrm{~cm}$ 程度の範囲で測定を行う。球電極には直径 $1.5 \mathrm{~cm}$ ，長さ $31.3 \mathrm{~cm}$ の支持棒を取り付けた。平板電極には ギャップ軸から $6.5 \mathrm{~cm}$ 離れた点を中心に, ケーブルを含め てマッチングをとった広帯域電界センサ(1) (センサ表面 の直径 $5 \mathrm{~cm})$ と, 軸上に直径 $1.5 \mathrm{~cm}$ の電流検出部を設けた。 電流測定にはロゴウスキコイルを用い，電流閉路中のイン ダクタンスが最小となるように同軸構造とし, 各種漂遊容 量との共振を避けた（図 1 ）。また，分割電極の周囲等か らコロナが生じないように支持部構造を工夫し，その効果 をイメージコンバータカメラで確認した。

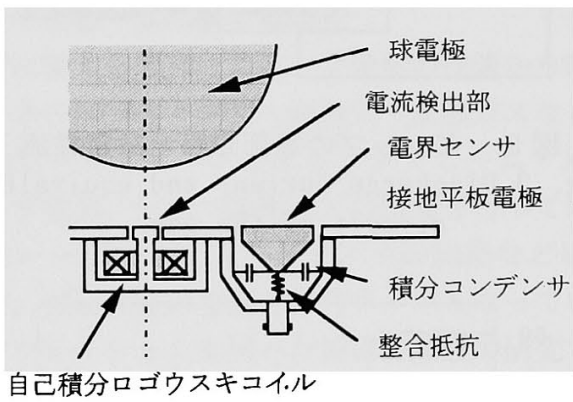

図 1 電界・電流検出部を持つ分割平板電極

Fig. 1 Subdivided plane electrode for electric field and current sensing.

\section{3. 測定誤差の検討}

<3. $1>$ 電圧測定の誤差先に述べた電圧測定の 誤差を評価するには放電路を考虑した電界計算が必要とな る。ここでは，ギャップを橋絡する放電路を，高さ方向に 電圧が変化する細い円柱抵抗として取り扱い，電荷重畳法 (2)による計算を行った。放電路の直径にはイメージコン バータカメラによる観測值 $(0.1 \sim 0.4 \mathrm{~cm})$ を用い，放電路 の長さ方向の電位分布が一様の時の平板電㥛表面の電界分 布を計算した。さらに，電界の変歪が大きい直径 $0.4 \mathrm{~cm} に$ ついて, 放電路内電位分布が極端に偏っている場合を想定

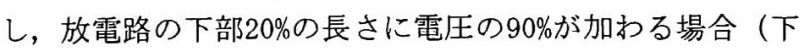
部高電位傾度）と上部 $20 \%$ に電圧の $90 \%$ 加わる場合（上部 高電位傾度）について電界計算を行った。図 2 にギャップ 長（d）が2cmの結果を示す。いずれの場合も, 電界セン サ表面上の電界変歪はほとんど無いことが事がわかる。d が長くなると変歪の範囲が広くなり， $\mathrm{d}=3 \mathrm{~cm}$ では電界セ ンサの端で約 $2 \%$ の電界変歪が生じるが，センサ表面全体 の平均電界の変化はその数分の 1 以下である。

急峻な放電電流が作る電磁界によるセンサ表面の垂直電 界成分は，これらの值より桁が小さい。 


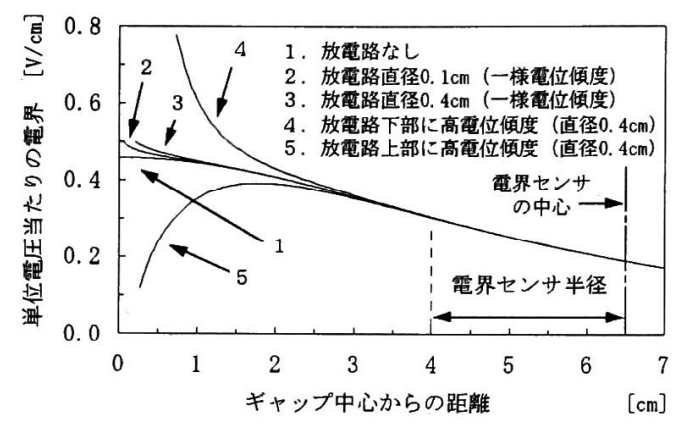

図 2 平板電極表面電界 $(\mathrm{d}=2 \mathrm{~cm})$

Fig. 2 Electric field intensity on the plane $(\mathrm{d}=2 \mathrm{~cm})$.

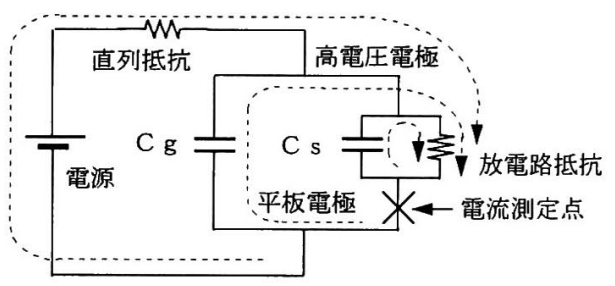

図 3 ギャップの等価回路と放電電流 Fig. 3 Discharge current and equivalent circuit of the gap.
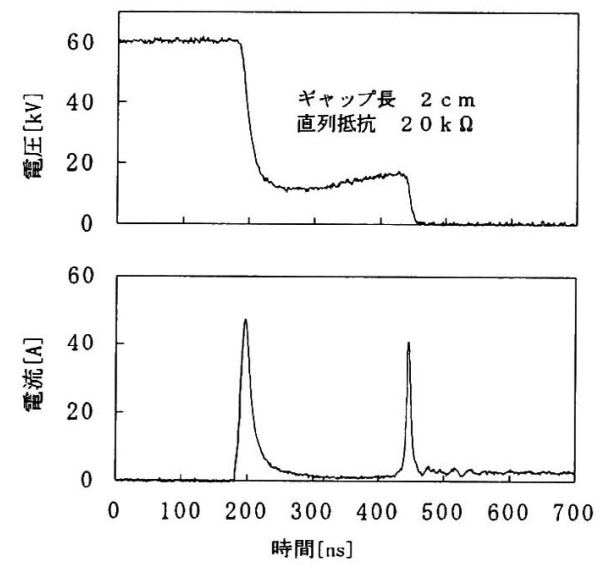

図 4 測定された電圧・電流波形

Fig. 4 Observed voltage and current wave forms.

\section{<3. $2>$ 電流測定の誤差}

電流検出部はギャッ プ軸を中心に広がりを持っているため電極電圧の変化によ り変位電流成分が流れる。この関係を, 図 3 に等価回路と して示す。球電極の対地容量 $(\mathrm{Cg})$, 電流検出部と球電 極間の静電容量 $(\mathrm{Cs})$ に変位電流が流れるが，Csを流れ る成分は測定電流に含まれないので誤差となり，その最大 值はCsと Cgの比で決まる。

電極支持部を含めた $\mathrm{Cg}$ と Cs 計算值をギャップ長毎に 表 1 に示す。表中の值から，Csによる電流の測定誤差は, 電圧測定とは逆に d が短い場合ほど大きくなるが，実験に

表 1 球電極の容量と電流センサ部の容量

Table 1 Capacitances of the sphere electrode and current sensor.

\begin{tabular}{|c|c|c|c|}
\hline & $\mathrm{d}=1 \mathrm{~cm}$ & $\mathrm{~d}=2 \mathrm{~cm}$ & $\mathrm{~d}=3 \mathrm{~cm}$ \\
\hline $\mathrm{Cs} / \mathrm{Cg}[\mathrm{pF}]$ & $0.148 / 20.2$ & $0.072 / 17.8$ & $0.046 / 16.6$ \\
\hline
\end{tabular}

用いる範囲では0.8\%以内であり，十分小さい事がわかる。

\section{4. おわりに}

測定電圧は並列標準球ギャップを用いて較正し, 測定電 流はロゴウスキコイルの感度較正で検出部全体の較正に代 えた。また, 応答試験を行なった結果, 電圧, 電流につい てそれぞれ70MHz，200MHzの広帯域測定であることが確認 できた。火花放電時のギャップ電圧・放電電流の測定例を 図 4 に示すが，階段状に降下する特徽的な電圧変化波形之 それに同期したパルス電流が 2 度観測されている。同図の 条件ではC s は C g 90.8\%以下なので, 放電路を流れるパ ルス電流の99. $2 \%$ 以上が放電電流として測定されている。 また, 直列抵抗を通じて流れる電流は約 3 A以下であった。

(平成 8 年 9 月 30 日受付, 平成 8 年 11 月 1 日再受付)

\section{文献}

(1) S. Yanabu, et al. :"ESTIMATION OF FAST TRANSIENT OVERVOLTAGE IN GAS-INSULATED SUBSTATION", IEEE Trans., on Pow. Delivery, Vol. 5, No. 4, $1875-1882,1990$

（2）河野，宅間：「数值電界計算法」, コロナ社, 1980

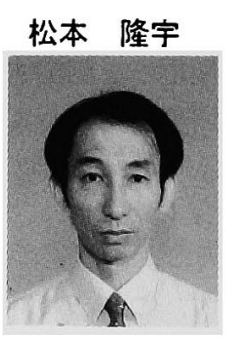

（正員）1952年 1 月 16 日生。 82 年 3 月 東京大学大学院博士課程修了。同年 4 月 より茨城大学工学部助手。 84 年 4 月よ り静岡大学工学部助教授, 現在に至る。 工学博士。主として, 高電圧計測とその 応用, 放電現象の研究に従事。

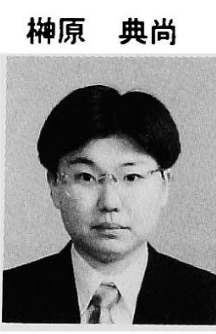

(学生員) 1972 年 12 月 26 日生。9 5 年 3 月静岡大学工学部電気 - 電子工学科卒 業。同年 4 月, 同学工学研究科電気工学 専攻修士課程に入学, 現在に至る。主と して, 放電現象の研究に従事。

黒川 正明

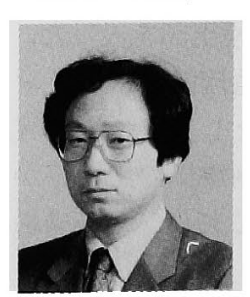

(正員) 1957 年 3 月 11 日生。 83 年 3 月静岡大学工業短期大学部卒業。7 9 年 4 月より静岡大学工学部文部技官, 現在 に至る。プラズマ, 放電現象等の研究に 従事。 